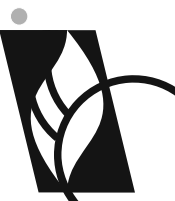

J O U R N A L

$\mathrm{O} F \bullet \mathrm{B} \mathrm{A} \mathrm{L} \mathrm{T} \mathrm{I} \mathrm{C}$

$S$ C I E N C E

E DUCATION

\section{ISSN 1648-3898}

Abstract. Scientific literacy is a principle objective of education almost in every country. It is mostly underlined in science education. Science education helps students become more productive individuals with the knowledge they acquire by promoting their thinking and learning skills and these skills help individuals to improve their scientific literacy. This research aims to determine the needs and problems in teaching science \& technology course in a special education middle school, attended by students with mild intellectual disability. This is a case study based on collecting and analyzing qualitative data. Semi-structured interviews, conducted with two teachers, 11 students, and their parents, researcher's diary, in class artifacts, field notes, and video recordings were used to depict the situation in the science \& technology course mentioned above. The data were analyzed through content analysis via Nvivo 10. Research findings display that the school in which this research study took place must be enriched with high technological tools; special education teachers' attitudes

towards the necessity of the science \& technology course for students with special needs must be improved; and teachers must be provided with knowledge and skills of differentiation and adaptation techniques to provide science \& technology activities in order for the science \& technology course to be taught in a more inclusive

manner.

Canan Sola Özgü Sakarya University, Sakarya, Turkey Atilla Cavkaytar Anadolu University, Eskisehir, Turkey

\section{SCIENCE EDUCATIDN FDR STUDENTS WITH INTELLECTUAL DISABILITY: A CASE STUDY}

\section{Canan Sola Özgüç, Atilla Cavkaytar}

\section{Introduction}

Science education not only makes students' progress academically but also socially by enhancing their interpretation and exploration of their environment. It helps students become more productive individuals with the knowledge they acquire by promoting their thinking and learning skills (Mastropieri, Scruggs, Norland, Berkeley, McDuffie, Halloran-Tornquist, \& Connors, 2006; Spooner, Knight, Browder, Jimenez, \& DiBiase, 2011; Stavroussi, Papalexopoulos, \&Vavougios, 2010). The main purpose of science education is to enhance scientific literacy. Scientific literacy is a contemporary issue underlined as an important educational objective in almost every developed country in the world. In the US, The American Association for the Advancement of Science [AAAS, 1989]) highlights under the title of Science for All Americans that all individuals in the society must be provided with scientific literacy. Science education is the primary source for developing skills necessary for scientific literacy. Similarly, Twenty First Century Science Project in UK indicates "all students need a central set of knowledge and skills to be scientifically literate citizens" (Villanueva, Taylor, Therrien, \& Hand, 2012; Millar, 2006). Consistent with these countries, in Australia one of primary reports of Department of Education, Training and Youth Affairs recommend to develop scientific literacy for all citizens (Rennie, Goodrum, \&Hackling, 2001). Scientific literacy is depicted as having knowledge of basic concepts and theories and basic skills required to establish the cause and effect relationship between the society and the environment (Holahan, McFarland, \& Piccillo, 1994; Martin, Sexton, \& Gerlovich, 2001). Several research studies, carried out to enable all individuals to receive science education, report that individuals with intellectual disability can acquire science concepts by receiving appropriate science education and can use the knowledge they acquire (Jimenez, Browder, Spooner, \& Dibiase, 2012; Mastropieri, et al., 2006; Villanueva, Taylor, Therrien, \& Hand, 2012; Watt, Therrien, Kaldenberg, \& Taylor, 2013). 
General education programs with no adaptations and their limited cognitive skills cause these students to experience academic failure in science \& technology course and this failure prevents them to access the general education program (Mastropieri et al., 2006). Cawley, Hayden, Cade and Baker-Krooczynski (2002) state that there is an inconsistency between the needs of students with special needs and the general education programs in schools. Therefore, students have difficulties in analyzing and synthesizing, as well as understanding cause and effect relationships due to deficiencies in their related skills. Thus, adaptation and differentiation must be employed so that these students can access the general education program (Mastropieri et al., 2006).

Since a great majority of individuals with intellectual disability are individuals having mild intellectual disability, most of these students receive science education in general education classes. Literature provides recommendations about how students with mild intellectual disability can make use of the general education program based on the fact that they cannot access the content of the general education program. As the aim of science education is to make all students science \& technology literate by considering individual differences, scientific literacy is one of the academic skills which all students are to be provided with just like reading skills and mathematics skills (NCLB, 2002).

Anderson and Anderson (2010) suggest that teaching practices must be supported with activities that address all senses of students and contain various materials so that all students can enjoy science education. Mastropieri et al. (2006) report that teaching practices based on textbooks and verbal lecture constitute a barrier for students with disability, which means a big problem for students who do not have reading \& writing skills. In this regard, research studies (Anderson \& Anderson, 2010; Mastropieri et al., 2006; Watt et al., 2013) show that the goals of the Individualized Education Programs (IEP) must be set by making modifications in the content of general education program and teaching activities must be carried out through differentiated instruction within the scope of the science education for students with disabilities.

Koga, College and Hall (2004) define curriculum modification as making certain changes in the curriculum components such as content, teaching method, and acquisitions in accordance with the needs of students. For example, while the science \& technology course curriculum involves the goal, "explain the meanings of concepts", this goal may be modified for students with intellectual disabilities as "show the named concept" or, if the students have reading \& writing skills, "match concepts and meanings" (King-Sears, 2001). Differentiated instruction is defined as determining the learning characteristics of students, providing students having different skills with appropriate teaching methods and instructional materials, and thus planning activities that will maximize their learning (Chard, 2014; Edyburn, 2004; Linn-Cohen, \& Hertzog, 2007; Olçay-Gül, 2014; Tomlinson, 2000; Tomlinson et al., 2003). In differentiated instruction, teaching activities are diversified through group instruction and individual instruction based on the fact that students in a class may have both common and different needs. In this way, teaching may be performed by use of various learning methods and tools in accordance with the interests and motivations of students (Anderson \& Anderson, 2010).

According to Edyburn (2004; 2006), differentiated instruction is an educational invention for dealing with the differences between students' academic levels, and technology plays an important role in differentiating assessment, instruction, and curriculum content. Accordingly, students can access the science $\&$ technology curriculum based on their needs if differences between academic levels confronted in science education are addressed through technological tools and differentiated instruction activities.

Olsen (2007) explored the effects of an activity-based middle school science lesson taught through technology-supported differentiated teaching on students' acquisitions in a unit. Pretest-posttest control group quasiexperimental design was used in that research. The research concluded that differentiated instruction performed through modification in the curriculum raised the achievement levels of students with special needs in science\& technology course. Moreover, the quality of the answers given by the students in the group receiving education through differentiated teaching has risen.

Spooner et al. (2011) explored the effectiveness of computer-aided direct instruction in teaching science concepts to three students with autism spectrum disorder and intellectual disability. In the general education class, the students acquired the covered three science concepts through instructions involving individual activities. Furthermore, maintenance and generalization were achieved.

Jimenez et al. (2012) explored the effectiveness of instruction with a fixed waiting time provided to five $(F=2, M=3)$ students with moderate intellectual disability who were at the age of 11 to 14 through their peers by use of the KWHL chart ( $\mathrm{K}=$ what do you Know?; $W=$ What do you want to know; $\mathrm{H}=$ How will you find out?; $\mathrm{L}=$ what did you Learn) during general education class (inquiry) science course activities. Multiple-probe across unit 
model, which is a single subject research method, was used in that research. Five students acquired eight science concepts in that research.

Assessment is an important part of teaching and it is as important as instruction. A research study on teachers' perceptions about their assessment practices in science \& technology course in a primary school was conducted by Skribe-Dimec and Vlahinja (2013). Research findings indicated that there was inconsistency between perceptions and practices. Although teachers stated that teaching science is demanding, they prefer to use traditional assessment methods such as oral and writing. Besides, it was determined that teachers used written assessment methods mostly for low cognitive level. Authors indicated that this research made teachers to raise awareness of their practices in science assessment.

Additional to research studies about teaching students with intellectual disability, Knight, Spooner, Browder, Smith, \& Wood (2013) explored the effectiveness of teaching concepts about convection to three students with intellectual disability and autism who were at the age of 13 to 14 through graphic organizers and explicit instruction and the influence of this teaching package on the generalization skills of students. Multiple-probe across students' model, which is a single subject research method, was used in that research. It was seen that three students acquired the concepts and established the relationship between graphic organizers and the concepts.

Similarly, Wood (2014) conducted a research employing the multiple-probe across subjects model in order to explore the effectiveness of systematic teaching (fixed waiting time) of students with moderate intellectual disability in posing and answering questions in science e-book. The research also investigated the generalizability of the students' understanding and answering of the questions posed within the scope of the science e-book to general education environments. All of the participants acquired the skills of answering correctly mentally and answering correctly through replaying the target section.

\section{Background to the Problem}

Literature contains limited research on science education of students with intellectual disability (Kaplan \& Ciftci-Tekinarslan, 2013; Knight et al., 2013; Jimenez et al., 2012; McGinnis, 2013; Spooner et al., 2011). It is seen in a lot of studies that science concepts are taught one-to-one. Jimenez et al. (2012) stated that science concepts can be taught to students with intellectual disability by use of one-to-one instruction through systematic teaching, but there is no effort for teaching them in the general education environment. On the other hand, students having mild and moderate intellectual disability receive science education together either with their peers with no disability or with their peers with intellectual disability (i.e. through group instruction). In addition, the review of science \& technology course curriculum implies that skills of putting the learned concepts into use and establishing cause and effect relationships should be taught to students besides teaching concepts to them. In this regard, determining how science education is given to students with intellectual disability in schools is important. On the other hand, McGinnis (2013) and Villanueva et al. (2012) argue that more research is needed in order for teachers to teach science better. The current situation must be determined in the first place in order to improve the quality of science \& technology lessons for students with special needs and make all students science literate. Based on this need, the present research aims to examine the science $\&$ technology course given in a special education middle school attended by students with mild intellectual disability and determine the needs and problems in practice. This research study also attempted to answer the below-mentioned questions: (a) What is general/physical environment of the school and classroom 6-A like? (b) How is the academic performance of students in the science \& technology course? (c) How do teachers design a course activity? (d) What kinds of learning problems are experienced in the science \& technology course? (e) What kinds of adaptations do teachers use in the science \& technology course? (f) What kinds of instructional materials do teachers use in the science \& technology course?

\section{Methodology of Research}

\section{General Background of Research}

This is a case study designed in a qualitative manner for determining the current situation in science \& technology course in a middle school special education classroom in Turkey. Case studies are widely used for examining new and complex situations in an integrated way, revealing the existing problems systematically, and developing services for the solution of these problems. In addition, it lights the way for future studies on subjects which have 
not been focused on much (Baxter, \& Jack, 2008; Creswell, 2014; Yin, 2008). It has to be determined that there is a special situation to be examined before a case study is carried out. For example, a case study can be designed if it is concluded at the end of the observations made in a field (e.g. school, class) for preliminary examination or if a special situation is detected through the informal interaction of a researcher. This case study took place in a school in which the first researcher has been providing internship counseling for the prospective special education teachers for six years. The researcher found out that topics covered in the science \& technology course did not go beyond simple concepts at the end of the observations and teacher interviews she did during these years. It was considered that the current situation of the course should be examined in a more detailed way and the instructions in science \& technology course needed to be improved. Yin $(2008$, p.13) states that case study is an important method to answer the questions of "how" and "why". Accordingly, this research was conducted to see how the science $\&$ technology course is taught and why very simple and basic science $\&$ technology concepts are included in the science \& technology course.

Case study has been categorized in various ways by research purpose, size of study group, and the characteristic of study group. The case study designs used in educational research most are those of Robert Yin. According to Yin (1994), there are four kinds of case study: holistic single case; embedded single case; holistic multiple-case; and embedded multiple-case. The present research attempts to describe the current situation in the science \& technology course in one class, therefore it employs "holistic single case". This research is limited with the science and technology class of a special education middle school. However, Bogdan and Biklen (2007, p.70) suggest that it may be difficult to manage a case study that is carried out in more than one place, so it should be conducted in a single setting. Since a case study focuses on a single unit, it seems more difficult to make a generalization compared to other kinds of qualitative research (Merriam, 2013). Stake (2005) states that it is possible to learn things from a specific case, and live descriptions can provide a picture. Although the research focused on a single class, the activities carried out in the class and the descriptions about them would provide a picture of the current situation for the efforts aimed at improving the quality of the science \& technology course provided in special education middle schools. For all these reasons, the research was conducted in class 6/A between October 2013 and March 2014.

\section{Setting}

This research was conducted in a special education middle school for students with mild intellectual disabilities in Sakarya, Turkey. It is a public school and is open between 09:00 and 15:00 every weekday. There is only one school that provides education for students with mild intellectual disability in the city where the researchers live. The research was planned to be carried out in one of the classes where problems about the science \& technology course had been detected. In addition, the voluntariness of the teachers was taken into consideration because the research would take a long time and include data collection tools such as observation and interview.

\section{Participants}

Two female teachers, teaching in 6-A, and graduated from the department of education of students with intellectual disabilities of a state university and their professional experiences range between 3 to 10 years, participated in this research. The other research participants were 11 students at the age of 11 to 13 who were diagnosed with mild intellectual disability, and their parents (nine mothers, one father). Semi-structured interviews with parents were conducted to obtain more information about students and students' science \& technology course performance (For instance, how they use knowledge, which they learnt in the science \& technology course in different settings). This information was used to verify the findings.

\section{The Researcher's Role}

Researcher's role changed throughout the study from being a non-participant to semi-participant observer. At the beginning of the research to determine the current situation, she was a non-participating observer. Then two months later, she interacted with the students and the teachers during the lessons and became a semi-participant observer at this point (Creswell, 2014, p. 235). 


\section{Data Collection}

The research data were collected in the science \& technology course between October 2013 and March 2014. The research data were obtained from observations, semi-structured interviews with the teachers, 11 students and 11 parents (10 mothers, 1 father) in-class artifacts, And the Researcher's Diary. The Data Collection Process is presented In Table 1.

Table 1. Data collection process.

\begin{tabular}{|c|c|c|c|c|}
\hline Data & Event & Time & Duration & Data collection format \\
\hline 03.10 .2013 & $\begin{array}{l}\text { Agreement with the } \\
\text { teacher }\end{array}$ & $10: 00-10: 04$ & $4 \min$ & Video recording \\
\hline 03.10 .2013 & $\begin{array}{l}\text { Agreement with the } \\
\text { manager of the school }\end{array}$ & $09: 40-09: 42$ & $2 \min$ & Video recording \\
\hline 03.10 .2013 & $\begin{array}{l}\text { Photos of the classroom } \\
\text { and the school taken, } \\
\text { and physical data ob- } \\
\text { tained }\end{array}$ & $11: 50-12: 10$ & $20 \min$ & $\begin{array}{l}\text { Field note } \\
\text { (Physical data) }\end{array}$ \\
\hline 24.10 .2013 & Parent meeting & 11:10-11: 36 & $26 \mathrm{~min}$ & Video recording \\
\hline $\begin{array}{c}24.10 .2013- \\
06.11 .2013\end{array}$ & Observations & $\begin{array}{l}09: 00-09: 40 \\
09: 55-10: 35\end{array}$ & $275 \min$ & Video recording \\
\hline $\begin{array}{l}13.11 .2013- \\
04.12 .2013\end{array}$ & Observations & $\begin{array}{l}09: 00-09: 40 \\
09: 55-10: 35\end{array}$ & $432 \mathrm{~min}$ & Field note \\
\hline $\begin{array}{l}18.12 .2013- \\
27.02 .2014\end{array}$ & Observations & $\begin{array}{l}09: 00-09: 40 \\
09: 55-10: 35\end{array}$ & $1133 \mathrm{~min}$ & Video recording \\
\hline $\begin{array}{l}\text { 08.01.2014- } \\
22.01 .2014\end{array}$ & $\begin{array}{l}\text { Interviews with the } \\
\text { students }\end{array}$ & \multicolumn{2}{|c|}{ (Total duration of interviews with the students) } & Semi-structured interview \\
\hline 24.01 .2014 & $\begin{array}{l}\text { Interviews with the class } \\
\text { teachers (Teacher 1) } \\
\text { (Teacher 2) }\end{array}$ & $\begin{array}{l}11: 00-11: 40 \\
12: 30-12: 46\end{array}$ & $\begin{array}{l}40 \mathrm{~min} \\
16 \mathrm{~min}\end{array}$ & Semi-structured interview \\
\hline $\begin{array}{c}22.01 .2014- \\
19.02 .2014\end{array}$ & $\begin{array}{l}\text { Interviews with the } \\
\text { parents }\end{array}$ & (Total duration of & vith 11 parents) & Semi-structured interview \\
\hline
\end{tabular}

\section{Observations}

Physical data related to the school and the classroom of the research were photographed and field notes were taken. Detailed observation for social data were obtained through field notes and video recordings. The observations were conducted between the $24^{\text {th }}$ of October and the $6^{\text {th }}$ of November. The researchers identified that the behaviors of the teachers and the students were not natural. The first author took field notes between the $13^{\text {th }}$ of November and the $18^{\text {th }}$ of December till students and the teachers got used to the researcher's presence. The observations between the $18^{\text {th }}$ of December 2013 and the $27^{\text {th }}$ of February 2014 were video-recorded for 30 hours. Since the teachers and the students did not behave naturally because of camera, data concerning the first two lessons (the $18^{\text {th }}$ of December) were excluded from data analysis. Thus, the researchers analyzed 28 course hours as observation data. During the observations, the steps to be followed in the observation process proposed by Creswell (2014) were taken into account (p. 237-238). The researcher firstly got into the setting and took general notes about the classroom. Then she acted as an observer and only made observations without participating in the course activities. At the end of the first two weeks, the researcher determined an observation aim and made observations based on that aim. The observations were aimed at determining; (a) science \& technology course teaching activities; (b) the learning characteristics of the students in the science \& technology course; (c) the learn- 
ing problems of the students in the science $\&$ technology course; and (d) the instructional materials used by the teachers and the adaptations made by them.

\section{Semi-structured Interviews}

The researchers intended to get the opinions of the students and the teachers in order to determine the current situation of the science \& technology course. Semi-structured interviews were conducted with the parents in order to obtain detailed information about the students. To this end, three different question forms were developed for the students, their parents, and the teachers. The questions were reviewed by one instructor who specialized in special education and one instructor who specialized in qualitative research. Their suggested revisions were incorporated and then the questionnaire were approved for use. In the beginning, pilot interviews were conducted with one mother, one teacher, and one student (Researcher's diary, p. 27). Actual interviews were carried out after the clarity of the questions was tested. All students participated in the interviews. The parent interviews were composed of nine mothers and one father. The parents of student- 9 did not participate. Interviews were conducted with two teachers. The interviews were tape recorded via a tape recorder. The interviews with the parents, the students, and the teachers took 300 minutes in total ( 158 minutes with 10 parents, 86 minutes with 11 students, and 56 minutes with 2 teachers). Then these tape-recorded interviews were transcribed.

\section{In Class Artifacts}

The researcher took the photos of the activity products made by the students in the science \& technology course and created a folder. Based on such data, the researcher developed an opinion about the skills of the students. Permission was obtained from the principal of the school, teachers, students and their parents to take photos of the artifacts.

\section{Researcher's Diary}

Researcher's diary provides valuable information into the research. It is collection of descriptions, analyses and interpretations. It provides a window on what goes on in the class (Mertler, 2006). In this research first researcher kept 72 page of diary. This data was used as supporting data.

\section{Data Analysis}

The first researcher and the second researcher selected the videos of seven out of the videos of 28 course hours for detailed analysis. The tape recordings obtained from detailed video analysis and other data collection methods were transcribed. $30 \%$ of the transcriptions were checked by a special education specialist, and the differences between the tape recordings and the texts were eliminated.

The data were analyzed through content analysis via Nvivo 10. The detailed transcriptions of the video recordings and the tape recordings, field notes, and the researcher's diary were transferred to Nvivo 10, and coded. The researcher reviewed the coding, grouped the relevant codes, for reduction from 35 to 21 codes. An individual specialized in special education qualitative research method as well as the authors examined the codes and the themes to identify corresponding data. The first researcher arranged the themes and associated them with the research questions in accordance with the suggestions provided (Mertler, 2006, p.127; Mills, 2003, p.112).

\section{Validity and Reliability}

Qualitative data collection techniques are intensely used in this research. According to Guba (1981), to be considered valid, qualitative research must fulfill the criteria of (a) credibility, (b) transferability, (c) dependability, and (d) confirmability (Brantlinger, 2005, p.201; Gay, Mills, Airasan, 2006, p. 403; Uzuner, 2005, p. 8).This research, meets above-mentioned criteria:

- Observations were made in the classroom environment for four months. The researcher initially observed the class activities by taking field notes so that the students and the teachers were used to the 
researcher. One month later, the researcher started to take video-recordings.

- The long-term nature of the observations ensured that the researcher was used to the environment, and the students, the teachers, and all the employees in the school considered the researcher part of the class.

- Since not natural behaviors were displayed in the first two lessons where camera was used, the data belonging to these lessons were excluded from analysis.

- The observations were documented by field notes and/or video-recordings.

- Semi-structured interviews were documented by tape recordings.

- Expert opinions were frequently used for ensuring the trustworthiness of the codes during the checking of tape recordings and video-recordings.

- The data obtained through various data collection techniques, which were among experience-based, document-based, and interview-based data collection techniques, were consistent with one another to ensure validity.

- All steps of the research were described in detail.

\section{Ethical Considerations}

Governorship's official permission and university's research ethics committee approval were obtained in order to carry out this research. The school administrator, the teachers, and the parents were informed of their roles and rights within the scope of the research. The parents stated that they saw no harm in the participation of their children in the research, rather they considered it is beneficial. Both teachers were voluntary to take part in the research.

Permission was obtained from the participants to use a tape recorder for tape recording throughout the research. Tape recording and video recording were kept only in the computer of the researcher and were not transferred to any another device. In addition, the teachers, the mothers, and the students were represented by code names.

\section{Results of Research}

\section{General/Physical Environment of the School and Classroom 6-A}

The school building is two-story. It is composed of three parts: Special Education Primary School; Special Education Middle School; and Vocational Training Center School. It contains 17 classrooms. It does not have any laboratory for science \& technology course practices.

The classroom where the research was carried out is on the second floor of the school building. Twelve desks and chairs were put in the classroom (U-shaped layout). As to the instructional materials in the classroom, there were no auditory, audiovisual, and interactive technological tools in the classroom. Since the classroom did not contain tools such as computer and projector needed by the teachers for the science \& technology course activities, some lessons were taught in the multipurpose room, and one lesson was taught in the computer laboratory. Figure-1 presents the sketch of the layout of the classroom where the research was carried out. 


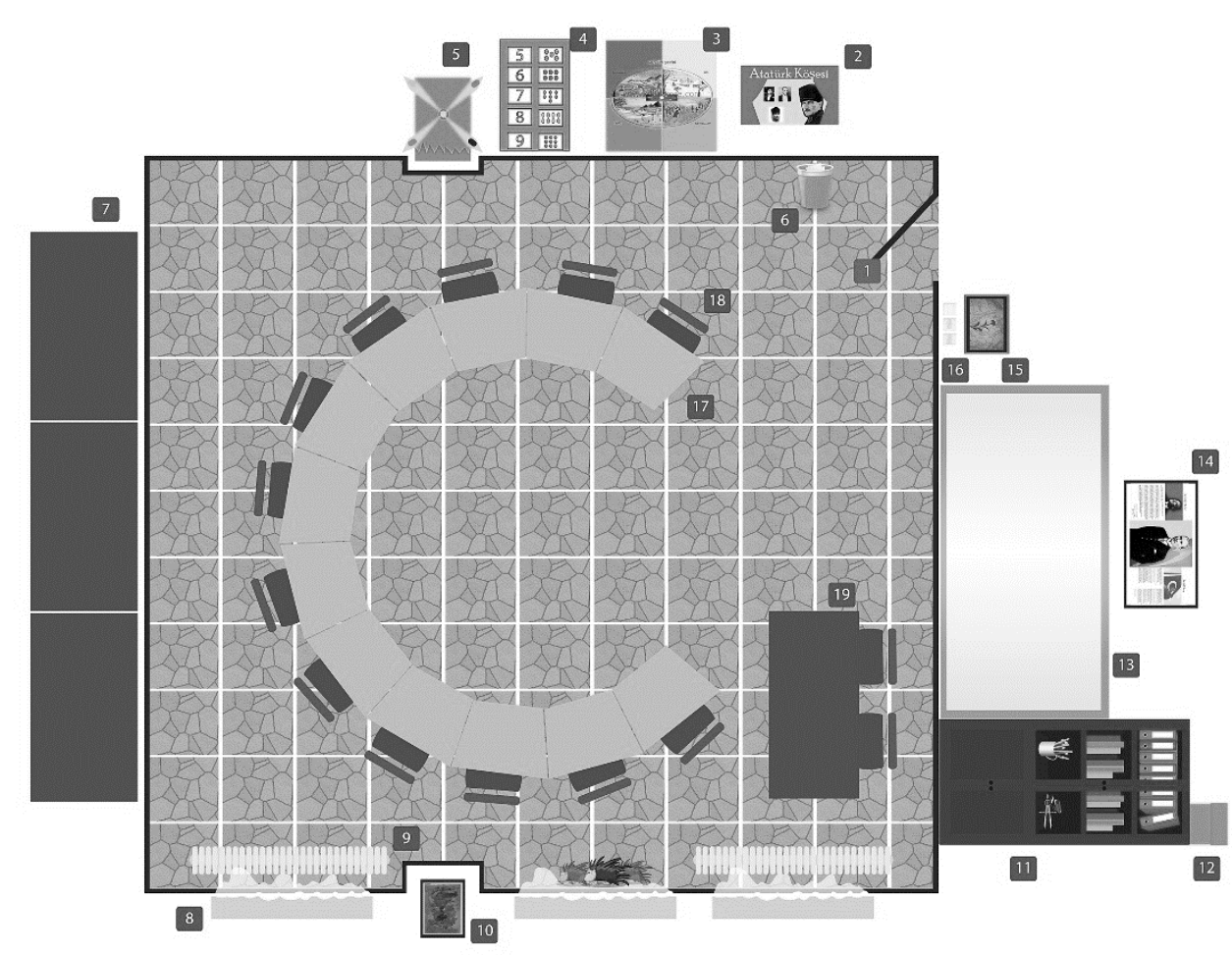

Figure 1: The sketch of the layout of classroom 6-A.

1) The door of the classroom / 2) The Atatürk corner / 3) The board of seasons / 4) The number table / 5) The windmill / 6) The waste bin / 7) Blank boards / 8) The window / 9) The radiator / 10) The painting / 11) The bookcase / 12) The hand-made box / 13) The white board / 14) The Turkish National Anthem, the Atatürk's picture, the Atatürk's Address to the Youth / 15) The picture / 16) The switches / 17) The students' desks / 18) The chairs / 19) The teacher's table]

\section{Students' Academic Performance in the Science \& Technology Course}

Teachers did not have records of academic performance of students in science \& technology course. Thus, the answer of this question was obtained from the video recordings, the students' artifacts, the interviews with the teachers, the students, parents, and the researcher's diary. During the research process, such sub-chapters of the unit titled "Let's Know Our Body" as locomotor system, digestive system, mouth and dental health, circulatory system, respiratory system, urinary system, and nervous system were taught in the classroom. Even though formal reports show that all students have mild intellectual disability, the performance of the students on these subjects indicated that the classroom had students from three different academic levels. Table 2 presents the characteristics of the students.

Table 2. Characteristics of the students.

\begin{tabular}{cccccl}
\hline $\begin{array}{c}\text { Performance of Students in } \\
\text { Science \& Technology Course }\end{array}$ & Students & Age & Gender & Disability Type \\
\hline & Student 1 & 13 & F & Mild intellectual disability \\
& Student 2 & 13 & M & Mild intellectual disability \\
High Level & Student 3 & 13 & F & Mild intellectual disability \\
& Student 4 & 12 & M & Mild intellectual disability
\end{tabular}




\begin{tabular}{ccccl}
\hline $\begin{array}{c}\text { Performance of Students in } \\
\text { Science \& Technology Course }\end{array}$ & Students & Age & Gender & \multicolumn{1}{c}{ Disability Type } \\
\hline & Student 5 & 12 & F & Mild intellectual disability \\
Student 6 & 13 & F & Mild intellectual disability / Down Syndrome \\
Student 7 & 12 & F & Mild intellectual disability \\
Student 8 & 14 & F & Mild intellectual disability / Limited expressive language \\
& & & & Mild intellectual disability \\
Student 9 & 12 & M & Mild intellectual disability / Down Syndrome \\
& Student 10 & 14 & M & Mild intellectual disability \\
\hline
\end{tabular}

The highest level included four students whose codes are Student 1, 2, 3 and 4. The students in that group have reading and writing skills. They can answer the questions about the previous lesson(s) asked by the teacher. These students listened to what the teacher taught during the lesson and answered the questions asked by the teacher about the lesson. These students made comments about the lesson and asked questions about unclear points to the teacher. Although there were some individual differences between these four students, all displayed interest in the science \& technology course. It was recorded during the observations that especially Student 3 had a special interest in the science and technology course. The mother of that student stated that Student 3 did a lot of experiments at home. The statement of the mother in this matter is as follows:

"My daughter is interested in everything she sees on TV. She wonders why the things she sees on TV are as they are.
She watches a program named Arka Bahçede Bilim [Science in the Backyard]. She tries to do what she sees in it. She
speaks about them. She tries to do the experiments she sees in it. She wants materials from me by saying, 'I'll do this
and I'll do that'. She wanted a broken CD on the other day. She saw it while going on the road. While she was passing
by, the CD gave out colorful lights. They attracted her attention. She looked at the Sun and then she looked at the
CD. As she saw colorful lights on it while it was turning around, the CD attracted her attention, and so she wanted
to show it to you."

Although the students in this group displayed interest in the science \& technology course, sometimes, they got bored and did not actively participate in the lessons while the teacher was teaching. This may be caused from teachers' under estimations about them such as being taught concepts simpler than their average level. The following extract from the observation of the lesson dated 13 November 2013 confirms these findings:

"The teacher said, 'We call this event as digestion and those working for it as digestion system.' Then she asked, 'What is it?' repeated, 'Mouth, esophagus, stomach, small bowel, large bowel'; and said, 'let's see their pictures now'. She showed the pictures of mouth, esophagus, stomach, small bowel, large bowel. Afterwards, she put the paper in her hand in front of the students one by one and told their names. She expected the students to tell the names, too. As they did not tell, she acted as a model. The students told with the teacher. Student 11 repeated what the teacher told. Student 10 and 11 repeated with the teacher. When the teacher asked, Student 8 murmured, 'mouth' and 'stomach'. Student 7 repeated the organs as the teacher told. Upon seeing the pictures, the Student 6 said, " $\mathrm{hmm}$ ". She repeated with the teacher. When the teacher asked, 'Shall we examine these?' Student 6 said, "Yes". Student 1 got bored and started to watch the outside. Student 9 swung on the chair backwards and forwards. After the teacher examined the pictures with Student 9, she examined them with Student 1 and 2 rapidly. Student 1 and 2 told mouth, esophagus, and stomach before the teacher told them."

The medium level included four students whose codes are Student 5, 6, 7 and 8. The students in this group did not learn reading and writing skills completely. The students undergo intensive reading \& writing practices. Student 8 had limited expressive language skills and could not participate in the lesson due to verbal limitations to answer the questions. The student was able to show the scientific concepts requested by the teacher on the picture. The other three students had similar performance in the science $\&$ technology course. The students were able to express the concepts from the previous lesson when they were reminded of such concepts. They were 
able to answer the questions asked by the teacher by using verbal cues. The students in this group are interested in the lessons. Especially Student 7 associated a topic covered in the lesson with a situation she experienced and was able to express an event he had experienced (Video record dated 20 November 2013). And this is one of the important skills need to be demonstrated for scientific literacy.

In class artifacts, the observations, and the teachers' interviews demonstrated that three low-level students were underdeveloped also in the fields other than science in comparison to their peers. These students are Student 9, 10 and 11. The students in this group are exposed to preliminary skills prior reading \& writing. They are very distracted. These students were able to perform the activities when the teacher set an example. In addition, these students were able to answer the questions asked when the teacher provided verbal cues and set an example. The students in this group failed to acquire the concepts taught in the units of urinary system and nervous system in particular. While they were able to name the organs whose pictures were showed to them in the units of digestion system and circulatory system, they failed to distinguish such organs in the nervous system as spinal cord and cerebellum. This may be because; these concepts are more concrete and are used in the daily life less (Video records dated 15 January, 22 January, 12 February, and 14 February 2014).

In brief, there were three different levels of achievement in the science \& technology course among the students, and the students had different needs.

\section{Design of a Science \& Technology Course}

Observation was made for 40 course hours throughout this research. The science $\&$ technology course was two hours on two days a week (two hours on each one of the two days). Teacher 1 carried out teaching activities on Tuesday, and Teacher 2 carried out teaching activities on Thursday. While Teacher 1 was teaching actively on Tuesday, Teacher 2 listened to and observed the lesson by sitting with the students and intervened in when any problematic behavior was displayed. Likewise, while Teacher 2 was teaching actively on Thursday, Teacher 1 listened to and observed the lesson by sitting with the students and intervened in when any problematic behavior was displayed. In addition, the teachers helped each other in activities such as painting and tool development throughout the lessons (Researcher's diary, p.11, 22, 26, 31, 36).

The teachers taught sub-sections of the unit entitled "Let's Know Our Body" through evidence-based direct instruction. Within the scope of the unit, systems, system organs, and the functions of organs were taught. After the teachers collected the attention of the students in the first ten minutes of the lessons, they reminded the previous topics. Then they proceeded to the new topic with a statement like, "Today we will study .......!"The teacher verbally lectured the new topic and made the students repeat the concepts related to the topic by asking them to the students one by one. After that, they presented the visuals related to the topic by use of low-tech tools most of the time. For instance, after the teacher verbally listed digestive system organs, she showed the pictures of organs to the students. She put organ pictures on the desks of 11 students and requested them to tell the names of the organs and show the organs whose names were told. After this activity was completed, the teacher finished the lesson with a general revision. The second lesson involved such activities about the topic as painting and watching a cartoon film and a general revision. It was observed in all lessons that the teachers allocated too much time to verbal lectures and the students just listened to them passively (Researcher's diary, p.11, 26).

\section{Learning Problems Experienced in the Science \& Technology Course}

The answer of this research question was obtained from the interviews with the teachers and the videorecordings of classes. Lack of permanence was seen to be the biggest learning problem among the students. It was observed that all the students in the classroom except for four students failed to answer the question, "What did we learn in the previous lesson?"Teacher 1 stated her opinions on this subject as follows:

"...We noticed that it is not permanent when it is auditory, but not visual. In the beginning, we just taught verbally..."

In addition, distraction prevented learning. The teacher explained that as follows:

“...Student 9 caught my attention. He was just distracted. He did not make an eye contact with me even while he 
was answering the questions I asked him. He was just haphazardly repeating what he saw. We failed to engage his attention. We had some problems with him..."

Moreover, it was observed that the learning problems of the students differed by unit. For example, while the digestion system organs and the respiratory system organs were more concrete for the students, the terms such as brain, cerebellum, and spinal cord were challenging for them, and even the students performing well (in high level group) in the science \& technology course had difficulty in naming them and distinguishing them on pictures (Video record dated 19 February 2014).

\section{Adaptations Teachers Use in the Science \& Technology Course}

The researcher indicated that in each IEP the same targets were set for the students. In a chapter, the teacher taught the same concepts to the low-level students and the high-level students. However, during the instruction it was observed that sometimes different instructions were given to the students. Verbal cues were given to the low-level students, but no cue was given to the high-level students. Although teachers knew how to individualize instruction, they did not make the individualizations in each student's IEP. The teacher 1 stated her opinions about the instructional adaptation as follows:

"For example, simplifying complex pictures for painting, etc., having them copied, and having students paint them... For example, I drew the picture about excretion by hand because we did not have a chance to have the existing format copied. It was black-and-white, complicated, small, and so on... We tried to draw them nicely."

The teacher 2 expressed her opinions as follows:

"We make adaptations for everyone in reading, writing, and mathematics courses, but we do not make any adaptation in science and social studies courses."

The teachers apparently delivered different opinions in response to this question. They focused on the different aspects of adaptation. Teacher 1 gave simplification, which is applied by them when they have difficulty in finding instructional materials appropriate to the levels of the students, as an example of adaptation. Teacher 2 stated lack of individualization in planning. In addition, it is clear that besides adaptations, contents and methods can also be differentiated in this class in accordance with the needs of the students. Some of the main points to be taken into consideration by the teacher while teaching the science \& technology course were seen to be as follows: There were three different levels of students in the class; student 8 had limited expressive language; and while some students had reading and writing skill, others did not. The researcher explained lack of differentiation for the students in assessment as follows:

“...The fact that the teachers do not make any assessment and adaptations prevent us from understanding how much the students learn. For example, Student 8 does not speak, and since Student 6 is a shy student, she does not want to answer the questions. That causes me to think that they do not learn the subjects. However, it is also possible that they can answer the questions visually or they can demonstrate what they learn in practice..." (Researcher's diary, p.9).

The table 3 given below presents the differentiations which are seen to be needed and the cases based on the findings obtained from the observations

Table 3. Cases on differentiations.

\begin{tabular}{lll}
\hline \multicolumn{1}{c}{ Case } & Expected & Observed \\
\hline 1. Limited expressive language & $\begin{array}{l}\text { Changing the way the student answers the question } \\
\text { asked by the teacher (e.g. answering by showing on } \\
\text { the picture) }\end{array}$
\end{tabular}




\begin{tabular}{lll}
\hline \multicolumn{1}{c}{ Case } & \multicolumn{1}{c}{ Expected } & Observed \\
\hline $\begin{array}{l}\text { 2. Differences in terms of reading \& writ- } \\
\text { ing skills }\end{array}$ & $\begin{array}{l}\text { Preparing worksheets involving questions about } \\
\text { systems in which high level students can also use their } \\
\text { reading \& writing skills }\end{array}$ & $\begin{array}{l}\text { Painting activity involving organ pictures for } \\
\text { every student }\end{array}$ \\
$\begin{array}{l}\text { 3. Non-equality of prior knowledge regarding } \\
\text { the science \& technology course }\end{array}$ & $\begin{array}{l}\text { Preparing an IEP for every student based on their } \\
\text { needs }\end{array}$ & Preparation of an IEP for all class \\
$\begin{array}{l}\text { 4. Student 3 doing experiments in the field of } \\
\text { science \& technology course and perform- }\end{array}$ & $\begin{array}{l}\text { An activity for teaching an experiment describing the } \\
\text { ing better than others in this course }\end{array}$ & $\begin{array}{l}\text { Painting activity on the subject of respira- } \\
\text { fory system }\end{array}$ \\
$\begin{array}{l}\text { 5. Difference in terms of the time of at- } \\
\text { tention }\end{array}$ & Hands-on activities based on student performance & $\begin{array}{l}\text { Verbal lecture in which 11 students listened } \\
\text { to the teacher passively }\end{array}$ \\
\hline
\end{tabular}

When the situations and the teachers' activities indicated in the table 3 are considered, it is seen that the students' needs and strengths are not taken into account much in lesson planning. It is a good example for teachers' underestimation for students.

Instructional Materials Teachers Use in the Science \& Technology Course

Table 4. Teacher use of instructional materials.

\begin{tabular}{|c|c|c|c|c|c|c|c|c|c|}
\hline \multicolumn{5}{|c|}{ Low-tech instructional materials } & \multicolumn{5}{|c|}{ High-tech instructional materials } \\
\hline $\begin{array}{l}\text { Pictures/ } \\
\text { Drawing }\end{array}$ & Book & $\begin{array}{l}\text { Two-dimensional } \\
\text { boards }\end{array}$ & Diagram & Puppet & $\begin{array}{l}\text { Computer } \\
\text { (15" laptop) }\end{array}$ & Tablet & $\begin{array}{l}\text { Smart } \\
\text { Phone }\end{array}$ & Video & Cartoon \\
\hline 26 & 3 & 22 & 1 & 2 & 4 & 4 & 1 & 2 & 2 \\
\hline
\end{tabular}

Table 4 summarizes the frequency of the instructional materials used based on the data obtained from the observations (28 hours video recordings). Pictures and drawings were identified as the most frequently used tools. It was observed that the teachers did not use the textbooks for teaching much. This may have been because; eight students in the class did not have reading and writing skills.

The teachers prepared a two-dimensional human body board (with a size of $120 * 60 \mathrm{~cm}$ ) for teaching the systems. During the teaching of each system, all the class drew and painted the organs learned on that board in cooperation. The board was one of the instructional materials used most during the observations. In two course hours in which they lectured on the locomotor system, the teachers erected a ragdoll (a puppet) to show that a person cannot stand upright without a musculoskeletal system. By putting a wire inside the second doll they developed, they demonstrated the importance of the locomotor system. That attracted the attention of the students a lot (Video record dated 5 November 2013; Researcher's diary, p. 15).

The teachers were eager to obtain some high technological (high-tech) tools with their own means. The computer of the official working in the school and the tablet computer of the teacher 1 were initially used by teachers in their science \& technology course. The tablet computer was used for displaying pictures about the lesson, and the computer of the official was used for watching cartoons and videos.

The teachers stated that if they were provided with high-tech tools, then the teaching activities would be more effective. The Teacher 1 expressed her opinions on this subject as follows:

"We wish we had one in our classroom and we could turn it on easily. We wish we had one computer and one projector. Then we can open and watch relevant things without delay and talk about them..."

"I wish there were a projector and a laptop in the classroom. For example, I wish we had color copies to show the pictures of the organs. I wish we had pictures which we could cut, and our students could paste and see by themselves..." 
The teacher 2 delivered her opinions on this subject as follows:

"Our most general need is computer. We experience difficulty because of lack of computer. We may need to do an activity in the science course or in any other course on a sudden. It is difficult to carry computer for this purpose."

"You may want to have children watch a cartoon. Or there may be slides or pictures related to the lesson to open. I think they would be used if every classroom had them. We need them especially in science and social studies courses because we need visuals in these courses. However, the school cannot supply them."

"We feel the deficiency of technological tools such as computer and printer which we can use for taking printouts. It would be different if we had them."

\section{Unexpected Findings of the Research}

Besides answering the research questions, the researcher also obtained some other findings. Through nonparticipant observation and a semi-participant observer, the researcher only observed the lessons and did not make any contribution to preparing and teaching the lessons. The researcher aimed to be in being a natural part of the class without intervening in it by any means and achieved it. The behaviors of the students and the teachers towards the researcher and their naturalness during the lessons confirmed that. However, attribution of the development of the students to the research and the researcher during the semi-structured interviews with the parents implied another situation. The parents stated in semi-structured interviews that there were unexpected improvements in the academic success of the students in the science \& technology course at the end of the process. The parents regarded this improvement as a product of the research process. One mother who thought that the researcher played an active role in the above-mentioned situation expressed her views as follows: "Now she is doing what you explain. For example, recently, she has taught trachea, esophagus, lung, and so on to Student 5 and Student 5 tells what comes after lung and so on." The mother of Student 7 stated, "But look! My child couldn't tell these things in the past and started to tell them after you came. There was nothing like that in the past. He used to do it in the past, but after you arrived, he also started to express them in this way or that way. Indeed, he is developing himself by this means." The mother of Student 11 spoke as follows: "My son tells us what he did about the lesson. In other words, he tells us what you tell him".

That made the researcher anxious in the first place. This is because; she thought that she had caused a change in the class though her aim was to describe the situation without intervening in. When she expressed it to the teachers, she learned that the teachers had not allocated the time specified in the curriculum (four hours in a week) for teaching the science \& technology course until she arrived. The following statement of Teacher 2 confirms that: "This year, we study science seriously and intensively. When we study in this way, we can succeed it. Children learn and enjoy. We've seen it. It has been a good experience for us, too." As the researcher said to the teachers that she would observe the science \& technology course, the teachers taught the science \& technology course for four course hours, as indicated in the curriculum. That enabled the students to develop a positive attitude towards the science \& technology course and improved their performance. The parents regarded that as a direct influence of the researcher.

\section{Discussion}

In this research, science \& technology lessons given in a classroom of a special education middle school were monitored for four months; the current situation of the science \& technology course given to students with mild intellectual disability was described; and students' and teachers' needs and the problems confronted in the teaching of the lessons were determined.

The classroom contained students from three different academic levels. The teachers were expected to take into consideration three different levels in developing content and using teaching strategies and instructional technologies. In other words, differentiation was also required because the students had different needs. This finding is consistent with Beard, Bowden-Carpenter, \& Johnston (2011) Chard (2014), King-Sears (2001), Koga (2004), and 
Prater (2006) who report that differentiation and adaptation are needed for students with intellectual disability to access the general curriculum. The general curriculum was followed in the class where the research was carried out. It was determined that adaptations and modifications were needed for the students to access the general curriculum because of their cognitive disability. The teachers made few adaptations in accordance with the students' needs. The teachers taught the same content and addressed questions to the students with limited expressive language skills for them to explain the concepts of respiration and circulation. In addition, the same targets were set for every student in the individualized science $\&$ technology curriculum. In addition, the fact that a large part of the 40-minute lessons was allocated to verbal lecture and just one instructional material was passed from one student to another caused the students to be distracted quickly. It is thought that non-use of hands-on activities allowing students to use the concepts they learn and the fact that they had to listen to the teachers by sitting passively restricted the skills they would acquire in the science $\&$ technology course. The results of the previous studies are consistent with this finding. Stavroussi et al. (2010) report that traditional teaching practices based on textbooks and verbal lecture are not effective in teaching science to individuals with intellectual disability. According to Knight et al. (2013), visuals such as graphic organizers attract the attention of students with intellectual disability and students with autism more in comparison to verbal lecture. Cognitive difficulties and distraction which are the basic learning problems of students with intellectual disability may be minimized through enriching and differentiating activities. The researcher expressed her opinions on this subject in her diary as follows: "I think no differentiation is made in the lessons. The teacher asks questions to the students one by one. That may be boring for the students and tiresome for the teacher."

It was realized in the semi-structured interviews conducted with the teachers that the topic entitled "Let's know our body" had been being covered for three years within the scope of the science \& technology course and the teachers did not incorporate any other topic in IEP. "Let's know our body", which is covered for three times all the year round, is very limited for students with mild intellectual disability. At this point, there is an obstacle to the access of the students to the general curriculum. The fact that topics which students with high academic skills already know are covered though they can enrich their life skills by learning different topics causes them to have limited knowledge of science. This may be explained with the low expectations of teachers regarding the success of students in the science \& technology course. Skribe-Dimec \& VIlahinja, 2013, report a similar result that teachers perceive their students with special needs as low achievers because of their cognitive constraints. Thus, special education teachers need to be aware of the fact that students with intellectual disability can be taught with appropriate instruction at a higher cognitive level and then their attitudes towards science education need to be improved.

In terms of instructional materials that could be used, classroom contained mostly two-dimensional instructional materials (low-tech technology) such as pictures, drawings, and boards made by the teachers. However, instructional materials that can increase the motivation of students with special needs through the provision of diversity are needed. This finding is consistent with the findings of the studies in the literature. Teachers use low technologies (low-tech) because they cannot procure high-tech tools (Avcıoğlu, 2012; Flanagan, Bouck, \& Richardson, 2012; Parikh, 2002; Sola Özgüç, \& Cavkaytar, 2014). Although a laptop and a tablet computer were used during the observations, the teachers procured these technologies through their own means. They stated that they had many difficulties in this matter. Observations were made for four months to ensure a natural research environment. Even though it was observed that teacher-student interactions were natural, the teachers exerted more effort for instructional material procurement and diversity in comparison to the natural teaching situation. Thus, it must be taken into consideration that less instructional materials may be used at other times. In addition, when they used high-tech tools, they failed use them very effectively. For instance, the teacher had the students watch a cartoon film on the small screen of a computer for $\mathbf{4 0}$ minutes, which was boring for the students. The teacher also had to show the pictures on the tablet to each student one by one, which caused a waste of time.

Lack of permanence and distraction was identified as learning problems common among the students. In this manner, it is thought that the concepts taught can be permanent only if teaching activities are enriched and associated with daily life skills (Edyburn, 2006).

There was a natural interaction with both the students and the teachers in the four-month observation process. However, a difference occurred when the researcher arrived in the environment although the four hours a week the science \& technology course, was not taught before the researcher arrived. It started to be taught so long after the researcher arrived. That increased the students' performance and interest in the course. It was seen that the students shared the concepts they had learned with their parents at home. The teachers reported that 
they had limited instructional materials, which resulted in they had difficulty in concretizing the science \& technology course and thus the students got bored of lessons containing verbal repetitions for four course hours. That may have caused the teachers to keep the science \& technology lessons shorter. This may also be because of the common view that reading-writing and mathematics courses are more important than the science \& technology course in making students acquire independent living skills. It should be kept in mind that the science \& technology course helps students to answer what and how questions regarding the events occurring around them and to make sense of what they live and experience (Villanueva et al., 2012).

\section{Conclusions and Implications}

In summary, the current situation was examined in terms of student and teacher needs and the problems encountered in teaching science \& technology lessons in the present research. It was observed that the teachers did not have high-tech tools, which affected the way and even the time the course was taught. When the tools were diversified even with the limited facilities of the teachers, the students became more interested in the science \& technology course, and positive changes occurred in their attitudes towards the course. The teachers did not have enough chance to make an effective use of the high-tech tools, which they had obtained through their own means. Besides, the teachers had limitation in making adaptations and differentiation to make students access to general education curriculum. What is more, the teachers had limited knowledge of the fact that science education helps students with intellectual disability to be independent individuals.

Research results show that special education schools should be enriched in terms of instructional materials; the attitudes of special education teachers towards the science $\&$ technology course should be improved; and teachers should be provided with knowledge and skills of differentiation and adaptation in science \& technology course activities so that the science $\&$ technology course is taught more functionally. Based on these results, the implications of this research are as follows: (a) The importance of science \& technology course should be highlighted, and necessary measures may be taken for teachers to allocate as much time as specified in curricula to science \& technology courses in special education middle schools. (b) Course contents regarding the use of high-tech tools should be updated and enriched in the undergraduate program of special education teacher training (c) Special education teachers' cooperation with science teachers may be encouraged to prepare activity-based science \& technology courses. (d) More research should be conducted to show how science $\&$ technology courses can be designed effectively making adaptations and differentiation and how students with intellectual disabilities can achieve in science \& technology courses.

\section{Acknowledgement}

This research is a product of the project no. 1402E032 supported by Anadolu University Scientific Research Projects Commission.

The authors would like to thank Ahmet Fidan for his help in estimating reliability. Also, the authors thank the children teachers, parents and manager of the school who took the time to participate in this research.

This research was presented as a poster presentation at 16th International Conference on Autism, Intellectual Disability \& Developmental Disabilities at Clearwater Beach, Florida, USA.

\section{References}

American Association for the Advancement of Science- AAAS (1989). Science for all Americans: Summary. Washington, D.C: AAAS.

Anderson, K. M., \& Anderson, C. L. (2010). Access to science for all students. Special Education Technology Practice, 12 (5), $19-24$.

Avcıoglu, H. (2012). Zihin engelliler sinif ogretmenlerinin arac-gerec kullanımına iliskin gorusleri [Intellectual disability class teachers' opinions on the use of materials]. International Journal of New Trends in Arts, Sports \& Science Education, 1 (2), 118-133.

Baxter, P., \& Jack, S. (2008). Qualitative case study methodology: Study design and implementation for novice researchers. The Qualitative Report, 13 (4), 544-559.

Beard, L. A., Bowden Carpenter, L., \& Johnston, L. B. (2011). Assistive technology access for all students (2nd Ed.). New Jersey: Pear.

Bogdan, R. C., \& Biklen, S. K. (2007). Qualitative research for education: An introduction to theories and methods. Boston: Pearson Education Ltd. 
Brantlinger, E., Jimenez, R., Klingner, J., Pugach, M., \& Richardson, V. (2005). Qualitative studies in special education. Exceptional Children, 71 (2), 195-207.

Cawley, J. F., Hayden, S., Cade, E., \& Baker-Krooczynski, S. (2002). Including students with disabilities into the general education science classroom. Exceptional Children, 68, 423-435.

Chard, D. J. (2014). Differentiating instruction for students with special needs. Indiana Department of Education. Retrieved December 6, 2015, from http://www.doe.in.gov/sites/default/files/curriculum/chard-special-education-paper.pdf.

Creswell, J. W. (2014). Educational research: Planning, conducting, and evaluating quantitative and qualitative research. Upper saddle river, New Jersey: Pearson Education, Inc.

Edyburn, D. L. (2004). Technology supports for differentiated instruction. Journal of Special Education Technology, 19 (2), 60-62.

Edyburn, D. L. (2006). Failure is not an option. Collecting, reviewing, and acting on evidence for using technology to enhance academic performance. Learning and Leading with Technology, 34 (1), 20-23.

Flanagan, S., Bouck, E. C., \& Richardson, J. (2012). Middle school special education teachers' perceptions and use of assistive technology in literacy instruction. Assistive Technology, 25 (1), 24-30.

Gay, L. R., Mills, G.E., \& Airasan, P. (2006). Educational research. Competencies for analysis and applications. New Jersey: Pearson Education Ltd.

Guba, E. G. (1981). Criteria for assessing the trustworthiness of naturalistic inquiries. Educational Communication and Technology Journal, 29, 75-92.

Holahan, G. G., McFarland, J., \& Piccillo, B. A. (1994). Elementary school science for students with disabilities. Remedial and Special Education, 15(2), 86-93.

Jimenez, B. A., Browder, D. M., Spooner, F., \& Dibiase, W. (2012). Inclusive inquiry science using peer-mediated embedded instruction for students with moderate intellectual disability. Council for Exceptional Children, 78 (3), 301-317.

Kaplan, G., \& Ciftci-Tekinarslan, I. (2013). A Comparison of knowledge levels of students with and without intellectual disabilities about astronomy concepts. Elementary Education Online, 12 (2), 614-627.

King-Sears, M. E. (2001). Three steps for gaining access to the general education curriculum for learners with disabilities. Intervention in School and Clinic, 37 (2), 67-76.

Knight, V. F., Spooner, F. Browder, Smith, D. M., \& Wood, C. L. (2013). Using systematic instruction and graphic organizers to teach science concepts to students with autism spectrum disorders and intellectual disability. Focus on Autism and Other Developmental Disabilities, 28 (2), 115-126.

Koga, N., College, B., \& Hall, T. (2004). Curriculum modification. Wakefield, MA: National Center on Accessing the General Curriculum. Retrieved January 17, 2015, from http://aim.cast.org/learn/historyarchive/backgroundpapers/curriculum_modification\#. VVr1bvntmko.

Linn-Cohen, R. B., \& Hertzog, N. B. (2007). Unlocking the GATE to Differentiation: A qualitative study of two self-contained gifted classes. Journal for the Education of the Gifted, 31 (2), 227-259.

Martin, R., Sexton, C., \& Gerlovich, J. (2001). Teaching science for all children. Massachusetts: Allyn and Bacon Company.

Mastropieri, M. A., Scruggs, T. E., Norland, J. J. Berkeley, S. McDuffie, K., Tornquist, E. H., Nicole, C. (2006). Differentiated curriculum enhancement in inclusive middle school science: Effects on classroom and high-stakes tests. The Journal of Special Education, 40 (3), 130-137.

McGinnis, J. R. (2013). Teaching science to learners to with special needs. Theory into Practice, 52, 43-50.

Merriam, S. B. (2013). Nitel araştirma desen ve uygulama için bir rehber.[Qualitative research a guide to designing and implementation] S. Turan (Ed.), Ankara: Nobel Yayın.

Mertler, C. A. (2006). Action research. Teachers as researchers in the classroom. Thousand Oaks, California: Sage Publications.

Millar, R. (2006). Twenty first century science: Insights from the design and implementation of a scientific literacy approach in school science. International Journal of Science Education, 28 (13), 1499-1521.

Mills, G. E. (2003). Action research: A guide for the teacher researcher (2nd ed.).Upper Saddle River: Merrill Prentice Hall.

No Child Left Behind Act [NCLB]. (2002) Pub. L. No. 107-110, 115 Stat. 1425. Retrieved December 8, 2015, from http://www2. ed.gov/policy/elsec/leg/esea02/107-110.pdf .

Olçay-Gül, S. (2014). Farklilastirilmis ogretim ve uyarlamalar [Differentiated instruction and adaptations]. Journal of Ufuk University Institute of Social Sciences, 5, 111-123.

Olsen, J. K. (2007). Impacts of technology-based differentiated instruction on special needs students in the context of an activity-based middle school science instructional Unit. (Unpublished Doctoral Dissertation). University of Arizona, Department of Teaching and Teacher Education, Arizona, ABD.

Parikh, R. M. (2002). Computing technology in special education (Unpublished Dissertation). University of Missouri, Columbia.

Prater, M. A. (2006). Teaching strategies for students with mild to moderate disabilities. New Jersey: Pearson Allyn \& Bacon.

Rennie, L. J., Goodrum, D., \& Hackling, M. (2001). Science teaching and learning in Australian schools: Results of a national study. Research in Science Education, 31, 455-498.

Sola Özgüç, C., \& Cavkaytar, A. (2014). Teacher use of instructional technology in a special education school for students with intellectual disabilities: A case study. Turkish Online Journal of Qualitative Inquiry, 5 (1), 51-65.

Spooner, F., Knight, V., Browder, D., Jimenez, B., \& DiBiase, W. (2011). Evaluating evidence-based practice in teaching science content to students with severe developmental disabilities. Research \& Practice for Persons with Severe Disabilities, 36 (1), 62-75.

Stake, R. E. (2005). Qualitative case studies. In N. K. Denzin \& Y.S. Lincoln (Eds.) The Sage handbook of qualitative research (3rd Ed.) (p. 443-466). Thousand Oaks, CA: Sage 
Stavroussi, P., Papalexopoulos, P. F., \& Vavougios, D. (2010). Science education and students with intellectual disability: Teaching approaches and implications. Problems of Education in the 21st Century, 19, 103-112.

Tomlinson, C. A. (2000). Differentiation of instruction in the elementary grades. Retrieved December 9, 2015, from http://eric. ed.gov/?id=ED443572.

Tomlinson, C. A., Brighton, C., Hertberg, H., Callahan, C.M., Moon, T.R, et al. (2003). Differentiating instruction in response to student readiness, interest, and learning profile in academically diverse classrooms: A review of literature. Journal for the Education of the Gifted, 27 (2/3), 119-145

Uzuner, Y. (2005). Ozel egitimden orneklerle eylem arastirmalari [Action research practices in special education]. Ankara University Faculty of Educational Sciences Journal of Special Education, 6 (2), 1-12.

Villanueva, M. G., Taylor, J., Therrien, W., \& Hand, B. (2012). Science education for students with special needs. Studies in Science Education, 48 (2), 187-215.

Watt, S. J., Therrien, W.J., Kaldenberg, E., \& Taylor, J. (2013). Promoting inclusive practices in inquiry-based science classrooms. Teaching Exceptional Children, 45 (4), 40-48.

Wood., A. L. (2014). Effects of systematic instruction on listening comprehension of science e-texts for students with moderate intellectual disability. (Unpublished Doctoral Dissertation). The University of North Carolina, Charlotte.

Yin, R. K. (1994). Case study research: Design and methods. Newbury Park,CA: Sage.

Yin, R. K. (2008). Case study research. Design and methods (4th Ed.) Thousand Oaks, CA: Sage.

\section{Canan Sola Özgüç}

Atilla Cavkaytar
PhD, Research Assistant, Sakarya University, Faculty of Education, Department of Special Education, 54300, Hendek - Sakarya, Turkey.

E-mail:csola@sakarya.edu.tr

Website: http://www.csola.sakarya.edu.tr

PhD, Professor, Anadolu University, Faculty of Education,

Department of Special Education, Yunusemre Kampusu, 26470

Eskişehir, Turkey.

E-mail: atilla.cavkayar@gmail.com

Website: http://home.anadolu.edu.tr/ acavkayt/ 